\title{
A Review on the Existing Service Quality Measurement Models
}

\author{
Berhanu Endeshaw \\ Department of Management, Kotebe Metropolitan University, Addis Ababa, Ethiopia \\ Email address: \\ Berhanu22012@gmail.com \\ To cite this article: \\ Berhanu Endeshaw. A Review on the Existing Service Quality Measurement Models. Science Journal of Business and Management. \\ Vol. 7, No. 4, 2019, pp. 87-94. doi: 10.11648/j.sjbm.20190704.13
}

Received: July 23, 2019; Accepted: September 6, 2019; Published: September 19, 2019

\begin{abstract}
The purpose of this review is to assess the existing service quality measurement models. A review of the literature was conducted utilizing keywords such as "definitions of quality", "meaning of quality", "service quality and features of service quality", "measurement models", specifically, "Gronroo's", "SERVQUAL", and "SERVPERF". These studies are selected from well-known databases - such as "Emerald", "ABI/Inform", "ScienceDirect", and "EBSCOhost". As yet, no consensus has been reached among scholars on the definition, indicators and factors of the quality of the healthcare services. Moreover, most of the current models are of Western origin and incongruent with the cultural and economic contexts of developing countries. From the review it is clear that none of the models are currently perfect in diverse cultures and no reliable generic model has yet been developed for measuring the quality of service. Generic models have failed to capture the real dynamism of the pragmatic environment, and can therefore be of limited practical use. Existing service-quality models have widely been criticised for the number and composition of the dimensions. All these models comprise of pre-defined dimensions that are non-specific to all service organisations. This is therefore advising organisations to develop their own models for measuring the quality of their services.
\end{abstract}

Keywords: Service Quality, Measurement Models, SERVQUAL, SERVPERF

\section{Introduction}

This paper contains a literature review on the various definitions of quality, service quality, features of service quality, quality-measurement instruments (frameworks and/or models) and also problems in that regard.

\section{The Meaning of Quality}

There seems to be varying understanding and definition of what is meant by quality, and even well-known authors define quality in different ways and views. The concept of quality has been considered to be one of the most debated subjects in the literature on services. The reason for this is a lack of consensus on how to define it [1-2].

The definition of quality has not yet given the same results throughout [3]. These authors emphasised the fact that irrespective of the time or context whereby quality is inspected, quality has got numerous definitions. The nature of service quality can be elusive because customers' needs and expectations are always changing. To keep up with the change, quality must be constantly managed and continually improved [4].

Some of the influential contributors and thought leaders regarding quality- improvement systems and theories about their existence today include: Crosby, Deming, Feigenbaum, Ishikawa, and Juran.

Quality was defined as follows:

According to Crosby [5], quality is compliance with the necessary criteria. It requires the requirements in order to measure the product or service quality. This shows whether it demonstrates of high or low quality in accordance with the set criteria. Crosby categorised quality as being either acceptable or unacceptable.

Deming [6] defined quality as follows: quality, whether it is product quality or service quality, is involving several dimensions to meets customer's expectations in order to satisfy customers. The central point in this definition is that the nature of quality is multidimensional and cannot be defined with only one feature so as to satisfy customers. 
Feigenbaum [7] defined quality based on three points: (1) quality product and service can be developed using the integrative efforts of the following departments, namely, marketing, engineering, manufacturing and maintenance. (2) Quality should also be defined in accordance with the needs and expectations of customer. (3) There is also a change in the definition of quality as customers' needs and expectations change from time to time.

Ishikawa's [8] defined quality in such a way that manufacturers are striving to produce products with quality so as to satisfy customers in accordance with their requirements. Ishikawa's fundamental point revolves how manufacturing companies can satisfy in the ever-changing needs and requirements of their customers. This leads quality should be defined in detail so as to satisfy customers.

Juran [9] defined quality based two different meanings: (1) Quality be composed of distinct attributes of product whereby it meets in accordance with customers' needs that results customer satisfaction, (2) Quality involves free from any deficiencies.

From the above definitions, it is clear that Crosby's definition focused entirely on quality as conformance to specification, while Deming, Feigenbaum, and Ishikawa defined quality as products and services that need to satisfy customers' in accordance with their needs and expectation. Juran's definition however rather incorporated specification and customer satisfaction simultaneously.

Apart from the above definitions by known gurus, there have also been definitions of quality by various other scholars. Aksu [10], for instance, defined quality as follows Quality is compliance with customer requirements to meet as planned. Wiele, Dale and Williams [11] presented a slightly different approach to quality, namely: Quality is defined as unexpected and that can take customer to a great pleasure.

In their definition of quality, Pycraft, Singh and Phihlela [12] and Stamatis [13] tried to be compatible with their views as follows: quality is done in the same way over time compliance with customers' expectations. Pycraft, et al [12] and Stamatis [13] used the word "conformance" indicating to meet a specification for the manufacturing industry.

Goodman, O'Brein and Segal [14] supported the previously mentioned points and stated as follows: quality is consistently producing in accordance with customer wants, while bringing down mistakes before and after delivering to the customer. This definition reflects how customers' needs can be fulfilled or exceeded - that is, the manufacturer delights the customer in order to achieve organisational reputation.

Dervitsiotis [15] defined quality differently; quality is defining as meeting or exceeding the needs and expectations of stakeholders. Stakeholders are who do have an interest in a business including customers, employees, government, etc. These stakeholders may have distinctive requirements and expectations, and it is a demanding task to address in accordance with their different needs and expectations.

Padma, Rajendran and Lokachari [16] supported the above-mentioned view, and pointed out that it is necessary to explore and satisfy customers and other stakeholders in order to achieve organisational objectives.

According to Grib [17], whose definition is the most comprehensive one, organisations need to define quality according to the specific context of the real environment. Azam, et al [4] and Raja, et al [18], among others. agreed with Grib's definition.

On the basis of the above analysis of definitions of quality, it can be concluded that it is vital to find common elements for arriving at a definition for this review. This review has therefore found the following components, namely (1) quality as perceived by the stakeholders, (2) conformance to specification, (3) context-specific and (3) meeting customer satisfaction. Hence, one can integrate and use the above common elements in order to define the quality of services.

\section{Service Quality}

Although initial attempts to define and measure service quality emanated mostly from the goods sector, Parasuraman, et al [19] were among the early researchers to point out that the concept of quality predominant in product as highlighted by researchers such as Garvin [25] is not extendable to the services sector.

Later, quality in products was considered to differ from quality in services [20-22], significantly so because as far as the physical product is concerned, the manufacturingoriented concept does not always appropriate to the nature of services. For instance, characteristics of the service process such as heterogeneity and the inseparability of production and consumption have made it hard to easily conceptualise the service process and its outcome as a solution to customer problems.

Another problem that was highlighted concerned the management of service quality, where quality of service is so difficult to identify and measures due to inherent features of services such as intangibility, perishability, simultaneity, and heterogeneity that make them differ from goods [23].

Quality of products can be measured objectively by indicators [20], however, quality of service is an abstract and difficult to construct due to unique characteristics such as intangibility, perishability, simultaneity, and heterogeneity [19, 24].

Redman [4] and Perrot [25] also supported the concept that the nature of service quality can be difficult because customers' needs and expectations are always changing. It follows that a large number of researchers attempted to develop ways for measuring the quality of service in their contexts.

Surprisingly, until now agreement has not reached on how to measure the quality of service [1, 2, 26-30]. Yet all researchers agree that the structure of service quality is a multidimensional and complex one [31]. This then lead to have a sound instrument to measure the quality of service. 


\section{The Features of Service Quality}

Although the four features of services, namely (1) intangibility, (2) perishability, (3) heterogeneity and (4) simultaneity were recognised to be important enough in developing a construct of service quality, the feature differences between services and products unable to adequately demarcate services from products and that the demarcation point out the manufacturer's interest, rather than the user's interest [32]. According to Lovelock and Gummesson [33], the traditional way of dividing products and services as long and out of date and this provides an opportunity to redefine services from a customer-based perspective.

What is universally acceptable, however, is that service quality is intangible because services are not easy to evaluate [34-35]. Because of this reason, service providers encounter a problem in finding out the perception of customers in their services [19].

The case for heterogeneity in services was primarily based on variations in the performance of the producers. Zeithaml and Bitner [36] however argued that no two customers are identical in their perception and hence would be defined differently, because the unique demands or experiences of the service would have been offered in a unique way.

Subsequently, Solomon and Stuart [37] argued that standardisation was undesirable for many services as most individuals preferred customisation.

One of the other features of services is perishability that cannot be kept for future use. Services are also perishable because many of them are simultaneously provided and consumed. It should be noted that many researchers regard perishability as a distinct feature that differentiates products from services.

Characteristics of the service process such as heterogeneity and inseparability of production from consumption have made it hard to conceptualise the service process and its outcome as a solution to customer problems.

According to Redman [4], Perrot [25] and Parasuraman, Zeithaml and Berry (38), the four distinctive characteristics discussed above meant that service quality is a more indefinable than product quality.

\section{Models for Measuring the Quality of Service Quality}

This section contains a review of various instruments (frameworks and/or models) for measuring the quality of services and the constructs of models developed by various leading academics. Measurement has been viewed as a precondition for management (it is impossible to manage as you cannot measure) as it gives the premise through which one can control and also used as a basis for improvement [39].

Several reasons have been given for the necessity of measurement, some of which are as follows: (1) to determine the results of quality-improvement practices, (2) to figure out what to focus on and improve, (3) to give a sign of bottlenecks and the cost of poor implementation, and (4) to set a standard that can help to compare something with.

Models (frameworks) not only help to learn which factors play a significant role in customer satisfaction, but also provide the guidelines for improvement. They give a simplified representation of the actual condition. Service quality models then help managers to recognize problems with regard to the quality of service and assist them to improve their efficiency, profitability and overall performance [40]. Various models have been developing and using to measure the quality of services. The problem in this case is that which among the models is best that could help to inform mangers for better decisions. The question that requires to be answered here is that 'Do the existing service quality measurement models suffice for measuring the quality of services? And for which service the model works best?

The following section presents a review of models and/or frameworks for measuring the quality of services. They were developed in different times.

\subsection{Gronroos's Model}

Gronroos's model was developed by Gronroos in 1984 and considered as the first model for measuring the quality of service [41]. The model highlighted how consumers compare services experienced with services expected when evaluating service quality, basically supporting the disconfirmation paradigm.

The model divided customers' experiences of a service into three dimensions, namely (1) technical quality, referring to the service delivery process, (2) functional quality, denoting how the service is delivered and (3) corporate image, which should have a positive impact on consumer perceptions.

Corporate image was not included in this review, because it is unchanging over time [42]. Functional and technical quality, however, are event-based and thus more controllable by the service provider and customers.

Gronroos [43] suggested that functional quality is by and large perceived quality to be more important than technical quality, the assumption being that technical quality is provided to the acceptable lever. According to Gronroos's model, how the services delivered are getting more attention in the quality of services.

According to Parasuraman, et al [38], customer-perceived service quality consisting of two dimensions, namely a process and an outcome dimension, whereas Gronroos [44] noted as functional and technical quality. Gronroos's model however only distinguished the components of service quality as technical and functional, without mentioning the tools (indicators) for measuring these components.

Thus, a combination of the above will be a basis for developing an appropriate framework for measuring the quality of services. 


\subsection{SERVQUAL Model}

The SERVQUAL model was first developed by Parasuraman, et al [38] and later refined by them in 1994. The model was intended to measure customers' perception of the quality of service in the context of American service organisations, with the emphasis on functional quality [45]. The SERVQUAL scale founds as an important discovery in the literature on how to measure the quality of service and is widely applied in different service organizations.

On the SERVQUAL model, Parasuraman, et al [19] presented that the quality of service is the differences between expectation and performance. This is known as the GAP model. Parasuraman, et al [19] identified ten dimensions for measuring the quality of service, namely (1) reliability, (2) responsiveness, (3) competence, (4) access, (5) courtesy, (6) communication, (7) credibility, (8) security, (9) understanding the customer, and (10) tangibles. In 1988, the same authors regrouping them into five dimensions, namely (1) reliability, (2) responsiveness, (3) tangibles, (4) assurance, and (5) empathy.

Parasuraman, et al [38] identified 22 indicators for measuring customers' expectations and perceptions. The factors and indicators of the factors included the following: reliability (four indicators), responsiveness (four indicators), tangibles (four indicators), assurance (five indicators), and empathy (five indicators). The instrument was administered twice, first for measuring expectations and secondly for measuring perceptions.

In the GAP model, as stated above the emphasis is on the relationship between a person's experiences as compared with his or her expectations [19, 46, 47]. As explained earlier in this section, when the perceived or experienced service is less than the expected service, the implication is that less than satisfactory service quality has been delivered. In the contrary, leads delight [38].

Wisniewski [48] and Lin, Chiu and Hsieh [49], supported the SERVQUAL model as it is valid and reliable for measuring the quality of service.

Wisniewski [48] further argued that, with minor modifications, SERVQUAL become adapted to any service organisation. Managers of service organisations just need to be mindful of how they use SERVQUAL in their particular context. It may also be required to conduct exploratory study in order to make sure that whether the SERVQUAL dimensions working and adding suitable ones in the intended service settings [50-51].

Many studies adapted and used SERVQUAL in a variety of contexts, reflecting the SERVQUAL measurement scale as their foundation, for example, banking [52]; hospitality [53] and education [59].

\subsection{SERVPERF Model}

Even though the SERVQUAL model can be adapted and considered as a foundation, many published SERVQUALbased studies on various conceptual and operational grounds criticised the instrument's psychometric soundness and usefulness. There were questions about the need for SERVQUAL's expectations component [30, 55], SERVQUAL's interpretation and operationalization of expectations lacking discriminant validity [56], and the generalizability of SERVQUAL's dimensions [57-58].

Moreover, Babakus and Boller [59] and Brown, et al [60] performed a confirmatory factor analysis (CFA) on SERVQUAL's dimensions and found it to be a poor model fit. These authors recommended a two-dimensional structure, namely, positively-worded items and negatively-worded items leading to a different score formulation with respect to the reliability and validity of SERVQUAL's.

The SERVQUAL model was also criticised for not incorporating the technical quality of the service. Even though the designers of the SERVQUAL scale assumed that it comprised of both the functional and the technical dimensions, it was deemed to lack any measure of technical quality [49]. Criticism was also raised against the stability of the dimensions of the SERVQUAL model and its focus on functional quality [61].

Rust, Zahorik and Keiningham [62] supported the idea of using a perception -minus expectation score but desired to measure the gap directly by requesting the respondents to provide their expectation in relation to actual performance. They suggested that the scale can reduce the length of the questionnaire and tend to be more reliable. Some authors [63] exhibited that earlier items could affect the respondents' feedback on the successive items. The varied comments about SERVQUAL led to further investigation of the factors of the quality of service and a means for some researchers to develop their own factors of quality of service.

Among some researchers, Cronin and Taylor [30] developed a performance only model called SERVPERF that helped to overcome the shortcomings of SERVQUAL. Above, it was pointed out that SERVQUAL directly measures both perceptions of expectations and performance, whereas SERVPERF measures only performance. It is assumed that the respondents are automatically comparing perceptions and expectations in to give their ratings.

Teas [56] argued in the SERVQUAL model that the justification given for expectation to measure the quality of service is inappropriate. In the past, several researchers (e.g. Dabholkar, Thorpe and Rentz [64] and Janda, Trocchia and Gwinner [65]) used performance-only scores and reported that approach to be superior to the disconfirmation approach for measuring service quality. A further criticism against SERVQUAL was that it fails to catch the changing of customers' expectation from time to time.

Cronin and Taylor [30] however maintained that the SERVPERF model had a reliability rate between 0.88 and 0.96 (demonstrating a high level of internal consistency reliability), and had a good convergent and a good discriminant validity. Brady, et al [66] replicated Cronin and Taylor's [30] research and confirmed that SERVPERF is superior to SERVQUAL scale. It is therefore considered as an appropriate model to measure the quality of services.

A number of authors [24, 29, 67] also demonstrated that 
Cronin and Taylor's performance-only model (SERVPERF) was better than SERVQUAL. SERVPERF has a higher validity and reliability than the SERVQUAL scores - in fact, the service-quality measurement tool is based on SERVQUAL.

\section{Conclusions and Criticisms}

Existing service-quality models have widely been criticised for the number and composition of the dimensions. All these models comprise of pre-defined dimensions that are non-specific to all service organisations. Even though the SERVQUAL model proved to be a robust measure for quality of service, many published SERVQUAL-based studies on various conceptual and operational grounds critically examined the psychometric soundness and usefulness of the instrument.

Further study of the SERVQUAL model was not helpful of its authors' claims. So that researchers produced different dimensions regarding expectations, perceptions and their differences in different settings. Consequently, SERVQUAL applicability to all cases and its divergent and convergent validity of the model were also questioned [30, 59, 68].

According to Martínez and Martínez [69], Babakus and Boller [59], Cronin and Taylor [30], Dabholkar, et al [70] and Teas [71], the major disparagement has been the use of perceptions minus expectations gap scores, the length of the instrument to collect data, the predictive ability of the instrument, and the validity of the dimensions.

A further criticism against the SERVQUAL scale had to do with its reliability and validity $[30,56]$. Cronin and Taylor [30] argued that the conceptualisation and put in to use the SERVQUAL scale was inadequate. This was confirmed as most authors could not replicate the five dimensions of the SERVQUAL model in different settings [30, 57, 59] and validity $(30,56]$.

The various tests carried out by Brandon-Jones and Silvestro [72] showed that both the SERVQUAL and SERVPERF model were reliable and valid, the latter being slightly higher performer. For such reason, SERVQUAL was considered insufficient.

The research discoveries demonstrated that SERVQUAL dimensions to be inconsistent, and SERVPERF to be a more precise model for measuring the quality of service as compared with SERVQUAL [30, 41].

As a result of ambiguity in the expectation section of the SERVQUAL model, researchers such as Carman (57) Babakus and Boller [59], Brown, et al [60], and Bolton and Drew (73), advocate the need for the development of a more appropriate model.

Cronin and Taylor disproved the SERVQUAL model and proposed a measure of quality of the service called SERVPERF. SERVPERF scale is an alternative to SERVQUAL model. The model reduced the number of items by $50 \%$ and was more efficient than SERVQUAL. There is considerable support over time appeared in the SERVPERF scale $[46,59,74,75]$. Zeithaml, one of the originators of the
SERVQUAL scale, admitted to the superiority of the SERVPERF model. Hence the SERVPERF scale was accepted even among researchers who previously had other views.

In general, although SERVQUAL and SERVPERF were considered as a common model to measure the quality of all types of services, it is vital to understand the model as a foundation that requires modification to fit into different settings.

Habbal [76] and Ladhari [77] no longer wished to rely on the SERVQUAL scale as a great deal remained to be addressed and learnt about the patient-physician relationship.

Although each of the above-mentioned models made a paramount contribution in the field of quality of service, it must be well known that they were developed specifically for the measuring of quality of service in a particular culture and sector and therefore whether and to what extent they are applicable to other cultures and sectors remains undetermined [78].

Karami, et al [79] definitely pointed out that cultural values have an influence on service-encounter quality perceptions. According to Murti, et al [80], service-quality dimensions developed in one culture may not be applicable in another culture. This has also support according to Malhotra, et al [81]; Smith and Reynolds [82]; Ueltschy and Krampf [83] that the models that work in Western culture for instance may not work in another.

According to Van Duong, et al [84], Herbig and Genestre [85] and Witkowski and Wolfinbarger [86] service quality dimensions developed in accordance with the context of that country culture can have influence on quality of services.

From the review it is clear that none of the models are currently perfect in diverse cultures and, as stated by Jain and Aggarwal, [78], no reliable generic model has yet been developed for measuring the quality of service.

Recently, Jain and Aggarwal [78] contended and listed the following points with respect to SERVPERF: (1) no explanation is given as to how resources can be integrated to excel in technical and functional service quality, (2) the model is not working for different types of services and need to be adapted in accordance with each service settings, (3) the model does not fit as far as different cultures are concerned, (4) the model requires to be examined in those industries which do involve highly (5) multiple measures of the dimensions have not yet studied.

Some researchers were of the opinion that prior research suggested that service quality is dependent on the service type and context, especially for people-delivered services [87-88].

Brady, Cronin and Brand [66] and Brown, et al [60] stated that according to the prevailing literature, the existing models used for measuring the quality of services that do not account for a specific context results in wrong conclusions. Dagger, Sweeney and Johnson [89] also supported the fact that businesses need to use a context-specific service-quality measurement in order to best understand consumers' perception of the service business. 
According to Brady, et al [66] and Cronin and Taylor [90], SERVPERF still posed a problem in that it used only 22 items of the SERVQUAL model. The criticisms raised against SERVQUAL were also raised against SERVPERF. The model could therefore be of limited benefit when trying to adapt it for practical usage.

Also, similar to the SERVQUAL scale, the SERVPERF model was developed based on customer perspective (functional quality) only, and not on technical quality. Moreover, no other stakeholders' opinions were considered for developing the model. As a whole, the model was so generic that it may not be applicable in different contexts.

All in all, it is thought that the existing literature has shown gaps regarding how to measure the quality of services as per the realistic environment in which the problem is found.

From the review it is clear that none of the models are currently perfect in diverse cultures and economy and no reliable generic model has yet been developed for measuring the quality of service.

\section{Recommendation}

It is recommended that every country and even every service delivery organization need to develop an appropriate framework for measuring the quality of their service according to their respective contexts.

\section{References}

[1] Azam, M., Rahman, Z., Talib, F. \& Singh, K. J. (2012), "A critical study of quality parameters in health care establishment: developing an integrated quality model", International Journal of Health Care Quality Assurance, Vol. 25 No. 5, pp. 387-402.

[2] Piligrimiene, Z. and Buciuuiene, I. (2011), "Exploring managerial and professional view to healthcare service quality", Journal of Economics and Management, Vol. 16, pp. 1304-1317.

[3] Reeves, C. A. and Bednar, D. A. (1994), "Defining quality: alternatives and implications", Academy of Management Review, Vol. 19 No 3, pp. 419-445.

[4] Redman, A. (2009), "Assessment and accountability", Journal of Health Services Research and Policy, Vol. 14 No. 4, pp. 249-250.

[5] Crosby, P. B. (1979), Quality is free, McGraw-Hill Book Co. New York.

[6] Deming, W. E. (1988), Out of the crisis. Cambridge, MA: Massachusetts Institute of Technology.

[7] Feigenbaum, A. V. (1983), Total quality control, 3rd edition, McGraw-Hill Book Co., New York.

[8] Ishikawa, K. (1985), What is total quality control? The Japanese way, Prentice-Hall Inc., Englewood Cliffs, NJ.

[9] Juran, J. M. (1988), Juran's quality control handbook, 4th ed, McGrawHill Book Co., New York.
[10] Aksu, M. B. (2003), "TQM readiness level perceived by the administrators working for the central organization of the ministry of national education in Turkey", Total Quality Management \& Business Excellence, Vol. 14 No. 5, pp. 591604.

[11] Wiele, T. V., Dale, B. \& Williams, R. (2003), "Business improvement through quality management systems", Management Decisions, Vol. 38 No. 1, pp. 19-23.

[12] Pycraft, M., Singh H. \& Phihlela, K. (2000), Operations management, Pearson Education, Pretoria.

[13] Stamatis, D. H. (2003), Six sigma and beyond: foundations of excellent performance. St. Lucie Press, New York.

[14] Goodman, J., O’Brein, P. \& Segal, E. (2000), "Turning CEOs into quality champions, Quality Progress", Vol. March, pp. 4754.

[15] Dervitsiotis, K. N. (2003b), "Beyond stakeholder satisfaction: aiming for a new frontier of sustainable stakeholder trust", Total Quality Management \& Business Excellence, Vol. 14 No. 3, pp. 511-524.

[16] Padma, P., Rajendran, C. \& Lokachari, P. (2010), "Service Quality and its Impact on Customer Satisfaction in Indian Hospitals, Perspective of patients and their Attendants, Vol. 17 No. 6, pp. 807-841.

[17] Grib, B. J. P. (1993), A critical literature study and research conducted on selected South African companies, University of Stellenbosch, Stellenbosch.

[18] Raja, M. P. N., Deshmukh, S. G. \& Wadhawa, S. (2007), "Quality award dimensions: a strategic instrument for measuring health service quality", International Journal of Health Care Quality Assurance, Vol. 20 No 5, pp. 363-78.

[19] Parasuraman, A., Zeithaml, V. A. \& Berry, L. L. (1985), "A conceptual model of service quality and its implications for future research", Journal of Marketing, Vol. 49 No. 4, pp. 4150 .

[20] Garvin, D. A. (1983), "Quality on the Line", Harvard Business Review, Vol. 61, pp. 65-73.

[21] Hollins, B. and Shinkins, B. (2006), Managing service operations: design and implementation, SAGE Publication Ltd. London.

[22] Parasuraman, A., Berry, L. L. \& Zeithaml, V. A. (1991b), "Understanding customer expectations of service', Sloan Management Review, Vol. 32 No. 3, 39-48.

[23] Sasser, W. E., Olsen, R. P. \& Wyckoff, D. D. (1978), Management of service operations, Allyn \& Bacon, Boston.

[24] Lee, H., Lee, Y. \& Yoo, D. (2000), "The determinants of perceived service quality and its relationship with satisfaction", Journal of Services Marketing, Vol 14 No. 3, pp. 217-231.

[25] Perrott, B. E. (2011), "Health service delivery in Australia: gaps and solutions", Journal of General Management, Vol 36 No. 3, pp. 55-66.

[26] Parasuraman, A., Zeithaml, V. A. \& Berry, L. L. (1994), "Alternating scales for measuring service quality: a comparative assessment based on psychometric and diagnostic criteria", Journal of Retailing, Vol. 70 No. 3, pp. 201-230. 
[27] Pai, Y. and Chary, S. (2012), "Measuring hospital service quality, a conceptual framework: in Proceedings of International Conference on Humanities', Economics, and Geography (ICHEG'2012), Bangkok, March, pp. 17-18: 192-195.

[28] Gupta, A., McDaniel, J. C. \& Herath, S. K. 2005. 'Quality management in service firms: sustaining structures of total quality service', Managing Service Quality, 15 (4): 389-402.

[29] Jain, S. K. and Gupta, G. (2004), "Measuring service quality: SERVQUAL vs. SERVPERF Scales". VIKALAPA, Vol. 29 No. 2, pp. 25-37.

[30] Cronin, J. J. and Taylor, S. A. (1992), "Measuring service quality: a re-examination and an Extension", Journal of Marketing, Vol. 56 No. 3, pp. 55-68.

[31] Nam, J. H. and Lee, T. J. (2011) "Foreign travelers' satisfaction with traditional Koreanrestaurants", International Journal of Hospitality Management, Vol. 30 No. 4, pp. 982989.

[32] Vargo, S. L. and Lusch, R. F. (2004), "Evolving to a new dominant logic for marketing", Journal of marketing, Vol. 68 No 1, pp. 1-17.

[33] Lovelock, C. and E. Gummesson. (2004), "Whither Services Marketing?", Journal of Service Research, Vol. 7 No. 1, pp. 20-41.

[34] Lovelock, C. H. (1981), "Why marketing management needs to be different for services", in Donnelly, J. and George, W. (Eds), Marketing of Services, American Marketing Association, Chicago, IL, pp. 5-9.

[35] Khan, M. (2003), "ECOSERV: eco tourists' quality expectations", Annals of Tourism Research, Vol. 30 No. 1, pp. $109-24$.

[36] Zeithaml, V. A. and Bitner, M. J. (2003), Services Marketing: Integrating Customer Focus across the Firm, 3rd ed. McGraw-Hill, New York, NY.

[37] Solomon, M. R., and Stuart, E. W. (2005), Marketing: real people, real choices, Prentice Hall, Upper Saddle River.

[38] Parasuraman, A., Zeithaml, V. \& Berry, L. (1988), "SERVQUAL: a multiple-item scale for measuring consumer perceptions of service quality", Journal of Retailing, Vol. 64 No 2, pp. 12-40.

[39] Owlia, M. S. (2010), "A Frame Work for Quality Dimensions of Knowledge Management Systems", Journal of Total Quality Management, Vol. 21 No. 11, pp. 1215-1228.

[40] Seth, N., Deshmukh, S. G. \& Vrat, P. (2006), "A conceptual model for quality of service in the supply chain", International Journal of Physical Distribution \& Logistics Management, Vol. 36 No. 7, pp. 547-575.

[41] Seth, N., Deshmukh, S. G. \& Vrat, P. (2005), "Service quality models: a review", International Journal of Quality \& Reliability Management, Vol. 22 No. 9, pp. 913-949.

[42] Swartz, T. A. and Brown, S. W. (1989), "Consumer and provider expectations and experiences evaluating professional service quality", Journal of the Academy of Marketing Science, Vol. 17 No. 2, pp. 189-95.

[43] Grönroos, C. (2001) "The perceived service quality concept a mistake", Managing Service Quality, Vol. 11 No. 3, pp. 4655 .
[44] Grönroos, C. (1984), "A service quality model and its marketing implications", European Journal of Marketing, Vol. 18 No 4, pp. 36-44.

[45] Brady, M. K., and Cronin, J. J. (2001), "Some new thoughts on conceptualizing perceived service quality: a hierarchical approach", Journal of Marketing, Vol, 65 No. 3, pp. 34-49.

[46] Churchill, G. A. and Surprenant, C. (1982), "An Investigation into the Determinants of Customer Satisfaction", Journal of Marketing Research, Vol. 19, pp. 491-504.

[47] Smith, R. A. and Houston, M. J. (1982), "Script-Based Evaluations of Satisfaction with Services," in Emerging Perspectives on Services Marketing, L. Berry, G., Shostack, and G. Upah, eds., American Marketing, 59-62, Chicago.

[48] Wisniewski, M. (2001), "Assessing customer satisfaction with local authority services using SERVQUAL". Total Quality Management, Vol. 12 No. 7\&8, pp. 995-1003.

[49] Lin, N., Chiu, H. \& Hsieh, Y. (2001), "Investigating the relationship between service providers' personality and customers' perceptions of service quality across gender", Total Quality Management, Vol. 12 No. 1, pp. 57-67.

[50] Millar, R. (2013), "Framing quality improvement tools and techniques in healthcare: the case of improvement leaders' guides", Journal of Health Organization and Management, Vol. 27 No. 2, pp. 209-204.

[51] Ladhari, R. (2009), "A review of twenty years of SERVQUAL research", International Journal of Quality and Service Sciences, Vol. 1 No 2, pp. 172-198.

[52] Olorunniwo, F., Hsu, M. K. \& Udo, G. J. (2006), "Service quality, customer satisfaction and behavioral intentions in the service factory”, Journal of Services Marketing', Vol. 20 No. 1, 59-72.

[53] Narayan, B., Rajendran, C. \& Prakash S. L. (2009), 'Scales to measure and benchmark service quality in tourism industry: a second-order factor approach', Benchmarking: $A n$ International Journal, Vol. 15 No. 4, pp. 469-93.

[54] Sohail, M. S. and Shaik, N. M. (2004), "Quest for excellence in business education: a study of student impressions of service quality", International Journal of Educational Management, Vol. 18 No. 1, pp. 58: 65.

[55] Babakus, E. and Mangold, W. G. (1992), "Adapting the SERVQUAL scale to hospital services: an empirical investigation", Health Services Research, Vol. 26 No. 6, pp. 767-86.

[56] Teas, R. K. (1993a), "Consumer expectations and the measurement of perceived service Quality", Journal of Professional Services Marketing, Vol. 57 No. 4, pp. 18-24.

[57] Carman, J. M. (1990), "Consumer perceptions of service quality: an assessment of SERVQUAL Dimensions", Journal of Retailing, Vol. 66 No. 1, pp. 33-55.

[58] Finn, D. W. \& Lamb, C. W. J. 1991. "An evaluation of the SERVQUAL scales in a retail setting", In Advances in Consumer Research, Vol. 18, edited by Rebecca.

[59] Babakus, E and Boller, G. W. (1992). "An empirical assessment of the SERVQUAL scale", Journal of Business Research, Vol. 24 No. 3, pp. 253-268.

[60] Brown, T. J., Churchill, G. A. \& Peter, J. P. (1993), "Improving the measurement of service Quality", Journal of Retailing, Vol. 69 No. 1, PP. 127-39. 
[61] Nagata, H., Satoh, Y., Gerrard, S. \& Kytömäki, P. (2004), "The dimensions that construct the evaluation of service quality in academic libraries", Performance Measurement and Metrics, Vol. 5 No. 2, pp. 53-65.

[62] Rust, R. T., Zahorik, A. J. \& Keiningham, T. L. (1995), "Return on quality (ROQ): making service quality financially accountable", Journal of Marketing, Vol. 59 (April), 58-70.

[63] Caruana, A., Ewing, M. T. \& Ramaseshan, B. (2000), "Assessment of the three-columnformat SERVQUAL: an experimental approach", Journal of Business Research, Vol. 49 No. $11 / 12$, pp. $57-65$.

[64] Dabholkar, P. A., Thorpe, D. I. \& Rentz, J. O. (1996) "A measure of service quality for retail stores: scale development and validation", Journal of the Academy of Marketing Science, Vol. 24 No. 1 pp. 3-16.

[65] Janda, S., Trocchia, P. J. \& Gwinner, K. P. (2002), "Consumer perceptions of Internet retail service quality", International Journal of Service Industry Management, Vol. 13 No. 5, pp. 412-31.

[66] Brady, M. K., Cronin, J. J. \& Brand, R. R. (2002), "Performance-only measurement of service quality: a replication and extension", Journal of Business Research, Vol. 55 No. 1, pp. 17-31.

[67] Johns, N., Avci, T. \& Karatepe, O. M. (2004), "Measuring service quality of travel agents: evidence from Northern Cyprus", The Service Industries Journal, Vol. 24 No. 3, pp. 82-100.

[68] Buttle, F. (1996), "SERVQUAL: review, critique, research agenda", European Journal of Marketing, Vol. 30 No. 1, pp. 8-32.

[69] Martínez, J. A. and Martínez, L. (2010), "Some insights on conceptualizing and measuring service quality", Journal of Retailing and Consumer Services, Vol. 17 No. 1, pp. 29-42.

[70] Dabholkar, P. A., Shepherd, C. D. \& Thorpe. D. I. (2000), "A comprehensive framework for service quality: an investigation of critical conceptual and measurement issues through a longitudinal study", Journal of Retailing, Vol. 76 No. 2, pp. 131-139.

[71] Teas, R. K. (1994), "Expectations: a comparison standard in measuring service quality: an assessment of a reassessment", Journal of Marketing, Vol. 58 No. 1, pp. 132-9.

[72] Brandon-Jones, A. and Silvestro, R. (2010), "Measuring internal service quality: comparing the gap-based and perceptions-only approaches", International Journal of Operations \& Production Management, Vol. 30 No. 12, pp. 1291-1318.

[73] Bolton, R. N. and Drew, J. H. (1991b), "A multistage model of customers' assessments of service quality and value' Journal of Consumer Research, Vol. 17 No. 4, pp. 375-84.

[74] Gotlieb, J. B. Grewal, D. \& Brown, S. W. (1994), "Consumer satisfaction and perceived quality: Complementary or divergent constructs?', Journal of Applied Psychology, Vol. 79 No. 6, pp. 875-885.

[75] Hartline M. D. and Ferrell O. C. (1996), "The Management of Customer Contact Service Employees: An Empirical Investigation", Journal of Marketing, Vol. 60 (October), pp. $52-70$
[76] Habbal, Y. (2011), "Patient's satisfaction and medical care service quality", International Journal of Business and Public Administration, Vol. 8 No. 2, pp. 95-112.

[77] Ladhari, R. (2008), "Alternative measures of service quality", a review managing service quality, Vol. 18 No. 1, pp. 65-86.

[78] Jain, P. and Aggarwal, V. S. (2015), "Service quality models: A review", BVIMSR's Journal of Management Research, Vol. 7 No. 2, pp. 125-136.

[79] Karami, M., Maleki, M. M. \& Dubinsky, A. J. (2016), "Cultural values and consumers' expectations and perceptions of service encounter quality", International Journal of Pharmaceutical and Healthcare Marketing, Vol. 10 No. 1, pp. $2-26$.

[80] Murti, A., Deshpande, A. \& Srivastava, N. (2013a), "Service quality, customer (patient) satisfaction and behavioral intention in healthcare services: exploring the Indian perspective", Journal of Health Management, Vol. 15 No. 1, pp. 29-44.

[81] Malhotra, N. K., Agarwal, J. \& Pererson, M. (1996), 'Methodological issues in cross-cultural marketing research: a state of the art review', International Marketing Review, Vol. 13 No. 5, pp. 7-43.

[82] Smith, A. M. and Reynolds, N. L. (2001), "Measuring cross cultural service quality: a framework for assessment", International Marketing Review, Vol. 19 No. 5, pp. 450-481.

[83] Ueltschy, L. C. and Krampf, R. F. (2001), "Cultural sensitivity to satisfaction and service quality Measures", Journal of Marketing Theory and Practice, Vol. 9 No. 3, pp. 14-31.

[84] Van Duong, D., Binns, C. W., Lee, A. H., \& Hipgrave, D. B. (2004), "Measuring client perceived quality of maternity services in rural Vietnam", International Journal for quality in Health Care, Vol. 16 No. 6, pp. 447-452.

[85] Herbig, P. and Genestre, A. (1996), "An examination of the crosscultural differences in service quality: the example of Mexico and the USA", Journal of Consumer Marketing, Vol. 13 No. 3, pp. 43-53.

[86] Witkowski, T. H. and Wolfinbarger, M. F. (2002), "Comparative service quality: German and American ratings across service settings", Journal of Business Research, Vol. 55 , pp. $875-881$.

[87] Jun, M., Peterson, R. \& Zsidisin, G. A. (1998), 'The identification and measurement of quality dimensions in health care: focus group interview results', Health Care Management Review, 23 (4): 81.

[88] Van Dyke, T. P., Prybutok, V. R., \& Kappelman, L. A. (1999), "Cautions on the use of the SERVQUAL Measures to assess the quality of information systems services", Decision Sciences, Vol. 30 No. 3, pp. 877-891.

[89] Dagger, T. S., Sweeney, J. C. \& Johnson, L. W. (2007), "A hierarchical model of health service quality: scale development and investigation of an integrated model', Journal of Service Research, Vol. 10 No. 2, pp. 123-142.

[90] Cronin, J. J. and Taylor, S. A. (1994), "SERVPERF versus SERVQUAL: reconciling performance- based and perceptionminus-expectations measurements of service quality", Journal of Marketing, Vol. 58 No. 1, pp. 125-131. 